\title{
Vegetation Recovery in Response to the Exclusion of Grazing by Sika Deer (Cervus nippon) in Seminatural Grassland on Mt. Kushigata, Japan
}

\author{
Takuo Nagaike, ${ }^{1}$ Eiji Ohkubo, ${ }^{2}$ and Kazuhiro Hirose ${ }^{3}$ \\ ${ }^{1}$ Yamanashi Forest Research Institute, Saisyoji 2290-1, Fujikawa, Yamanashi 400-0502, Japan \\ ${ }^{2}$ Yamanashi Gakuin Junior College, Sakaori 2-4-5, Kofu, Yamanashi 400-8575, Japan \\ ${ }^{3}$ Minami-Alps City Office, Ogasawara 376, Minami-Alps, Yamanashi 400-0306, Japan \\ Correspondence should be addressed to Takuo Nagaike; nagaike-zty@pref.yamanashi.lg.jp
}

Received 30 November 2013; Accepted 6 January 2014; Published 19 February 2014

Academic Editors: H. Ford, P. K. S. Shin, P. M. Vergara, and J.-t. Zhang

Copyright (C) 2014 Takuo Nagaike et al. This is an open access article distributed under the Creative Commons Attribution License, which permits unrestricted use, distribution, and reproduction in any medium, provided the original work is properly cited.

\begin{abstract}
We examined the recovery of vegetation in seminatural grassland in central Japan after eliminating grazing by sika deer (Cervus nippon) by fencing. By 2012, after 5 years of fencing for exclusion of sika deer, the species composition of quadrats within the enclosure reverted to the original species composition in 1981, not browsed by sika deer. Conversely, outside the fence was different from the baseline quadrats in 1981. Iris sanguinea, a prominent flower in the area, recovered within the enclosure, while it continued to decrease with grazing outside the fence. Nevertheless, the I. sanguinea cover had not recovered to the 1981 levels in the enclosure. Fencing can effectively restore vegetation as the species composition within the enclosure gradually reverts to the original vegetation. Preventing grazing in intensively grazed seminatural grassland might lead to different successional pathways. Since $I$. sanguinea did not recover fully within the enclosure and the species composition differed slightly from the original vegetation, this suggests that the vegetation within the enclosure will change to an alternative state. Therefore, different management is needed to promote the correct succession pathways for ecological restoration, perhaps by enhancing the colonization of target species, to prevent restored sites from giving rise to alternative states.
\end{abstract}

\section{Introduction}

Traditionally, seminatural grasslands in Japan have been managed for grazing cattle and harvesting agricultural materials (e.g., fertilizer; [1]). However, most of these have been abandoned with changes in lifestyle and farming methods [2], as in other countries (e.g., [3]). In Japan, forests cover $78 \%$ of the land area [4] and the mild, humid climate promotes the growth of forests [5]. Consequently, abandoned grasslands are invaded by trees and are important especially for early successional species and species favoring open habitats (e.g., [6]). So, such seminatural grassland has a high priority to conserve biological diversity.

Recently, the population of sika deer (Cervus nippon) in Japan has increased sharply because of the declining numbers of hunters and their aging, extinction of predator, and so on $[7,8]$. The effects of deer on natural grassland vegetation have been reported worldwide (e.g., [9]). In Japan, deer have had serious effects on natural forests $[10,11]$, plantations $[12,13]$, and grasslands $[14,15]$. Since sika deer prefer open habitats as foraging sites [16], patchy grasslands surrounded by forests are used heavily by sika deer. Consequently, the plant species composition in the grasslands has been altered markedly by grazing sika deer.

On Mt. Kushigata (2053 m a.s.l. at the summit) in central Japan, seminatural grasslands are distributed patchily with plantations and fragmented natural forests [17]. In the grassland, the flowers of Iris sanguinea and other meadow species (e.g., Veronicastrum japonicum) had been renowned. However, those flowers have been decreasing since 2000 because of grazing by sika deer. As countermeasures for the grazing, fences were set in the grassland in 2007. Fencing is effective for recovering from herbivore grazing $[18,19]$ and promotes tree regeneration $[20,21]$. The effects of grazing exclusion 
from seminatural grasslands on species richness [22] and spatial patterns [23] have been studied. However, undesirable results, in which execution at ecological restoration might lead to alternative states [24], can occasionally occur when fencing is used as a tool for conservation in overgrazed environments [25]. Therefore, restoration efforts should be checked by comparing the results with the restoration target $[3,4]$.

This paper presents the vegetation recovery pattern in seminatural grassland in central Japan after preventing grazing with fencing and addresses the following question: can $I$. sanguinea and vegetation community recover to the original situation and community before they were affected by sika deer?

\section{Methods}

2.1. Study Site. The study was conducted on Mt. Kushigata (2053 $\mathrm{m}$ a.s.l. at the summit), Yamanashi Prefecture, in the cool-temperate zone of central Japan $\left(35^{\circ} 35^{\prime} \mathrm{N}, 138^{\circ} 22^{\prime} \mathrm{E}\right)$. The mean annual precipitation and temperature at the nearest meteorological station (Oizumi, $867 \mathrm{~m}$ a.s.l.) are approximately $1140 \mathrm{~mm}$ and $10.7^{\circ} \mathrm{C}$, respectively. The estimated mean annual temperature at the summit of Mt. Kushigata is about $3.5^{\circ} \mathrm{C}$. Snow cover is usually less than $1 \mathrm{~m}$.

On Mt. Kushigata, seminatural grasslands are distributed patchily with plantations and fragmented natural forests [17]. The origin of the grassland is not clear, but elevations in this region around $2000 \mathrm{~m}$ are typically dominated by subalpine coniferous forests composed of Abies and Tsuga species. The grassland was probably the result of human activity, such as mowing or burning. We studied the Hadakayama area of Mt. Kushigata. Hadakayama means "naked mountain," which indicates that this area has not been covered by forest for a long time. The grasslands in the Hadakayama area are renowned for the flowers of I. sanguinea. Over a 10-year period, however, the number of I. sanguinea flowers has decreased, possibly as a result of the natural succession from grassland to the typical subalpine coniferous forest. Grazing by sika deer was another potential reason. Therefore, fences to exclude sika deer were erected to prevent grazing in 2007.

2.2. Field Study. In July 1981, the science club of Koma High School studied the vegetation in the Hadakayama area [6]. They set $321 \times 1 \mathrm{~m}$ quadrats in the Hadakayama area typically dominated by $I$. sanguinea and applied the standard BraunBlanquet scale: + , sparse cover; (1) cover $<5 \%$; (2) cover 5$25 \%$; (3) cover $25-50 \%$; (4) cover $50-75 \%$; (5) cover $75-100 \%$. The species composition in 1981 is considered the original vegetation not affected by grazing by sika deer.

In October 2007, we established a $20 \times 20 \mathrm{~m}$ plot and fenced half of it $(10 \times 20 \mathrm{~m})$ to protect it from deer grazing. The quadrats set by Koma High School were $20 \mathrm{~m}$ from the plot. In June 2008, we established $201 \times 1 \mathrm{~m}$ quadrats, 10 inside and 10 outside the fence, and conducted annual surveys from 2008 to 2012 using the Braun-Blanquet method. We counted the number of individuals of $I$. sanguinea in each quadrat every year.
2.3. Analysis. Koma High School [6] did not list all rare species (i.e., species with low coverage in the quadrats studied). Therefore, we analyzed the species with coverage with a score $>1$ on the Braun-Blanquet scale.

We used nonmetric multidimensional scaling (NMS; [27]) to provide an ecologically interpretable quantification of the compositional differences among original vegetation (1981) and quadrats inside and outside the fence (20082012). NMS applied Sørensen's similarity index to calculate a distance matrix. We used the species cover in each quadrat for NMS after transforming the Braun-Blanquet scale quantitatively. The data transformed to cover values (the midpoints of the cover intervals for each score) were used; that is, scores of 1 to 5 were converted to the values $2.5 \%, 12.5 \%, 37.5 \%, 62.5 \%$, and $87.5 \%$, respectively [26]. NMS was performed using PCORD [27].

To show the recovery of I. sanguinea, we compared the number of individuals and cover.

\section{Results}

The recovery of $I$. sanguinea inside the fence was good, while outside the fence, it decreased continuously with grazing (Figure 1). The number of flowering I. sanguinea also increased inside the fence to 25 in 2010, 198 in 2011, and 307 in 2012, while no flowers occurred outside the fence (unpublished data, Committee of Conservation of $I$. sanguinea at Mt. Kushigata). Nevertheless, the I. sanguinea cover had not recovered fully compared to 1981 (Figure 2).

The changes in the number of species inside and outside the fence showed contrasting trends (Figure 3). The number of species increased inside the fence, but not outside it. The species composition differed markedly inside and outside the fence (Figure 4). In 2008, most of the quadrats were located in the upper left position in the NMS diagram. Then, the species composition of the quadrats within the fence shifted to the upper right position in the diagram, where the species composition in 1981 was located (i.e., not browsed by sika deer). Conversely, the species composition of the quadrats outside the fence was shifted to the lower right. Species that occurred in more quadrats inside the fence were Dianthus superbus var. longicalycinus, Phedimus aizoon var. floribundus, Serratula coronata, and Chamerion angustifolium as well as I. sanguinea (Table 1). Angelica pubescens, Veronicastrum japonicum, and I. sanguinea, which were categorized by tall herbs, were only dominant inside the fence. Brachypodium sylvaticum and Ranunculus japonicas were less dominant before grazing but were dominant after exclusion of sika deer. Outside the fence, Artemisia princeps initially dominated, and subsequently the graminoids Stipa pekinensis and B. sylvaticum, which appeared to be unpalatable, dominated.

\section{Disscusion}

Exclusion of sika deer by fencing was successfully recovering the cover and number of individuals of I. sanguinea because those outside the fence were continuously low. Thus, effects of grazing by sika deer were continuously severe. In 


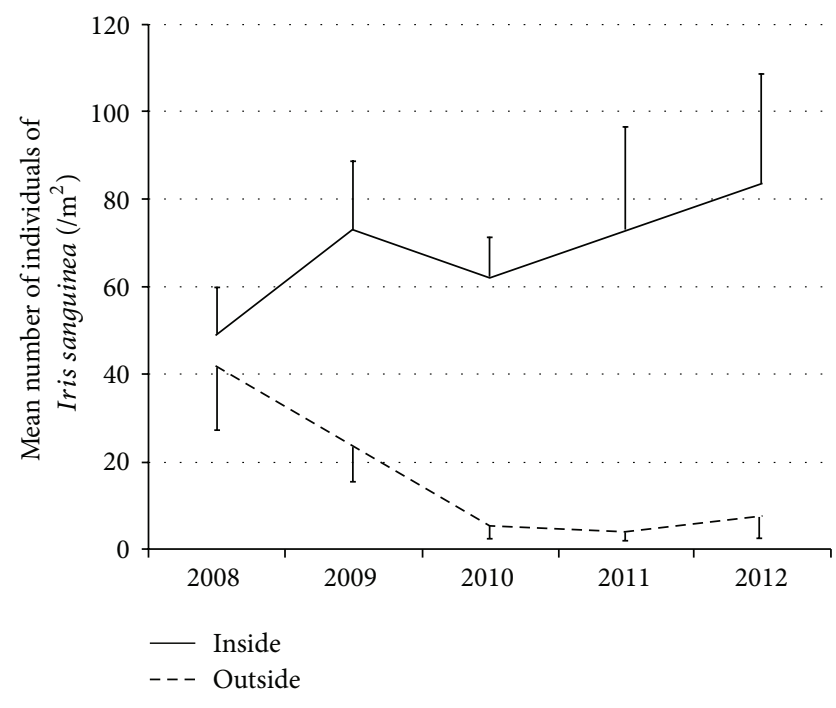

FIGURE 1: Changes of mean number of individuals of Iris sanguinea in each quadrat. Vertical bars showed standard deviation.

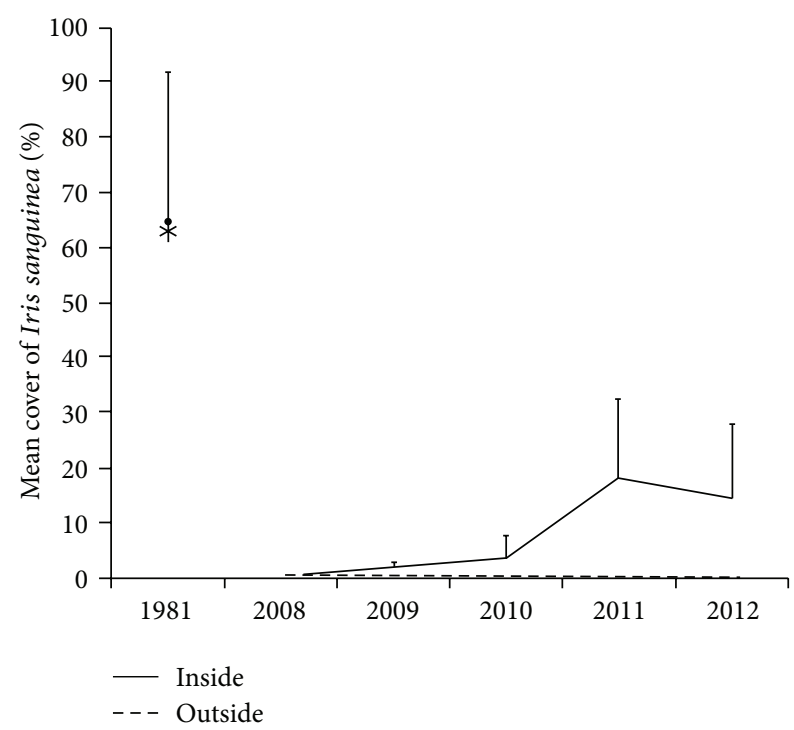

Figure 2: Changes of mean cover of Iris sanguinea in each quadrat. Vertical bars showed standard deviation.

the seminatural grassland of northern Japan, Iris setosa dominated the most at sites grazed by horses, which improved the surface soil characteristics [28]. In our study, sika deer grazed on I. sanguinea directly, causing serious damage. Thus, to conserve I. sanguinea, fencing seems necessary under the present circumstances. Since Tamura [29] showed that vegetation recovery, particularly tall herb species, was poor when fencing was delayed, it will be impossible for $I$. sanguinea to recover fully even if fences are erected now. However, I. sanguinea would not recover fully compared to situation before grazing despite preventing grazing.

Fencing appeared to be effective at restoring the vegetation as the species composition in the fence gradually

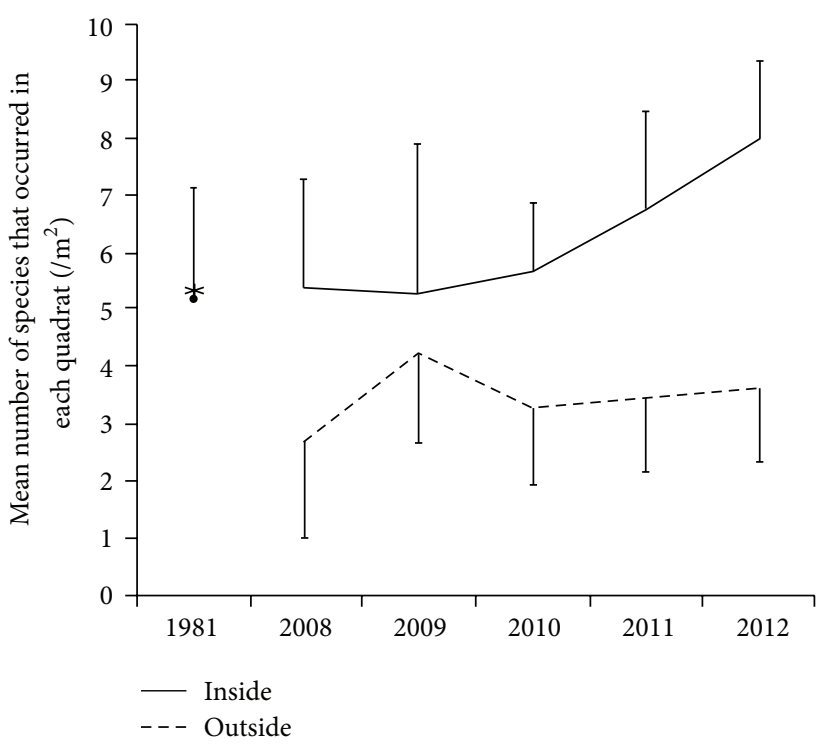

FIgURE 3: Changes of mean number of species that occurred in each quadrat. Vertical bars showed standard deviation.

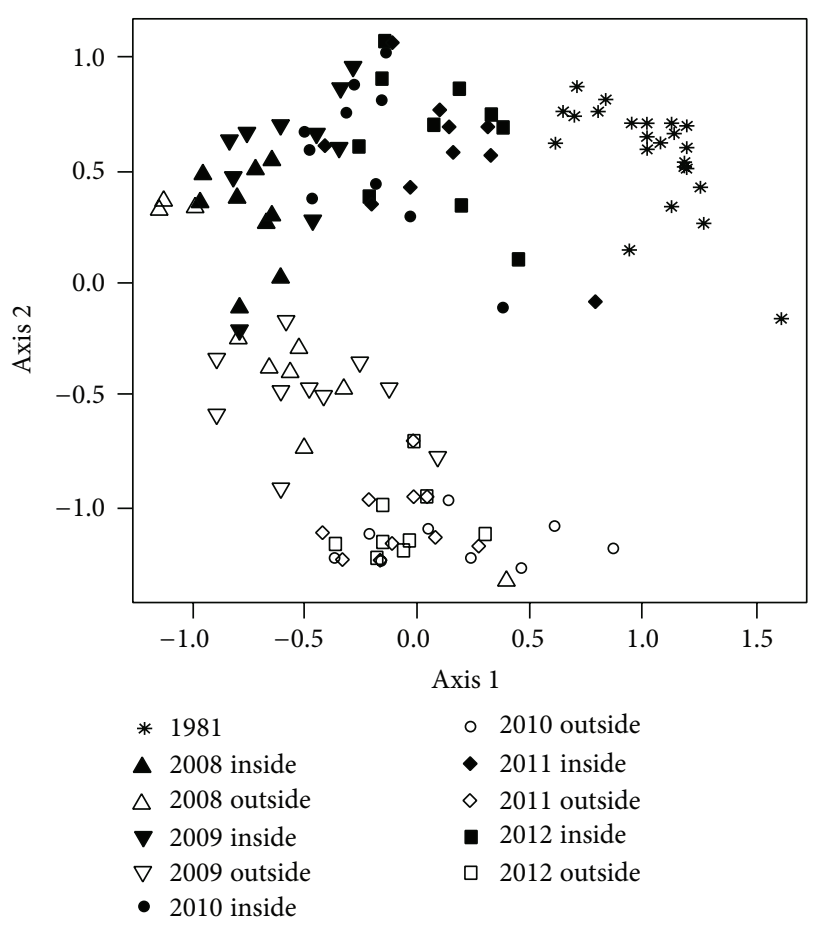

FIGURE 4: Results of nonmetric multidimensional scaling (NMS) for species that occurred in each quadrat.

reverted to the original vegetation. Herbivores often, but not always, increase plant diversity in grasslands [30]. Outside the fence, however, since the species composition was altered and the number of species was low, intense grazing pressure by sika deer likely existed.

Rooney and Dress [31] showed that species with relatively lower abundance were more likely to be missing due to 
TABLE 1: Species list in each quadrat. Figures in the table show number of quadrats in species occurred. The total number of quadrats is 36 in "before grazing," 10 in "inside the fence," and 10 in "outside the fence," respectively.

\begin{tabular}{|c|c|c|c|c|c|c|c|c|c|c|c|}
\hline \multirow{2}{*}{ Species } & \multirow{2}{*}{$\begin{array}{c}\text { Before grazing } \\
1981 \\
\end{array}$} & \multicolumn{5}{|c|}{ Inside the fence } & \multicolumn{5}{|c|}{ Outside the fence } \\
\hline & & 2008 & 2009 & 2010 & 2011 & 2012 & 2008 & 2009 & 2010 & 2011 & 2012 \\
\hline Adenophora remotiflora & 1 & & & & & & & & & & \\
\hline Adenophora triphylla & 3 & & & & & & & & & & \\
\hline Agrostis clavata & & & & & & & & & 1 & & \\
\hline Anaphalis margaritacea & 2 & & & & & & & & & & \\
\hline Angelica pubescens & 2 & 4 & 3 & 2 & 3 & 5 & & & & & \\
\hline Aquilegia buergeriana & & 1 & 1 & & & 1 & & & 1 & & 1 \\
\hline Arabis hirsuta & & 1 & & & & & & 1 & & & \\
\hline Arenaria serpyllifolia & & & & & & & & & & & 1 \\
\hline Artemisia princeps & 2 & 10 & 10 & 8 & 7 & 8 & 9 & 9 & & & \\
\hline Astilbe microphylla & 6 & & & & & & & & & & \\
\hline Brachypodium sylvaticum & & 3 & 2 & 4 & 4 & 3 & 5 & 7 & 8 & 10 & 10 \\
\hline Campanula punctata & 2 & & & & & & & 1 & & & \\
\hline Chamerion angustifolium & 6 & & & & & 1 & & & & & \\
\hline Cirsium gratiosum & & & & & & & & 1 & 1 & 1 & 1 \\
\hline Clinopodium chinense subsp. grandiflorum & & 5 & & & & & 2 & & & & \\
\hline Dianthus superbus var. longicalycinus & & & & 1 & 3 & 2 & & & & & \\
\hline Dryopteris expansa & 4 & & & & & & & & & & \\
\hline Filipendula multijuga & & & & 1 & & 1 & & & & & \\
\hline Fragaria nipponica & & 4 & 4 & 2 & 3 & 4 & & 3 & 1 & 2 & 2 \\
\hline Geranium onoei & 14 & & 1 & 2 & 5 & 9 & 1 & & & & \\
\hline Gymnadenia conopsea & & & & 1 & & & & & & & \\
\hline Hakonechloa macra & 2 & & & & & & & & & & \\
\hline Iris sanguinea & 23 & & 6 & 9 & 10 & 10 & & 1 & & & \\
\hline Ixeridium dentatum & 1 & & & & & & & & & & \\
\hline Jacobaea cannabifolia & 4 & & 2 & 4 & 4 & 4 & 2 & & & & \\
\hline Ligularia dentata & 1 & & & & & & & & 1 & 1 & 2 \\
\hline Malus toringo & & & & & & & 1 & 1 & & & \\
\hline Moehringia lateriflora & & 3 & 2 & & & & 1 & & & & \\
\hline Oxalis corniculata & & & & & & & & 1 & 2 & 3 & 3 \\
\hline Phedimus aizoon var. floribundus & 1 & & & & 1 & 2 & & & & & \\
\hline Picris hieracioides & 1 & & & 1 & 2 & & & 1 & & & \\
\hline Polygonatum odoratum & 3 & & & & & & & & & & \\
\hline Polygonum cuspidatum & 1 & & & 1 & 1 & 3 & & & & & \\
\hline Potentilla freyniana & & 4 & 5 & 1 & & 2 & & & & & \\
\hline Ranunculus japonicus & 1 & 10 & 8 & 8 & 8 & 8 & 2 & 5 & 2 & 4 & 3 \\
\hline Scabiosa japonica & 8 & & 1 & 2 & 2 & 1 & & & & & \\
\hline Serratula coronata & 19 & 1 & & & 2 & 2 & & & & & \\
\hline Solidago virgaurea & 4 & & & & & & & & & & \\
\hline Stipa pekinensis & & 1 & & & & & 4 & 8 & 10 & 10 & 10 \\
\hline Tephroseris flammea & 3 & & & & 1 & & & 2 & 6 & 4 & 3 \\
\hline Veronicastrum japonicum & 12 & 7 & 8 & 10 & 9 & 10 & & 1 & & & \\
\hline Viola acuminata & & & & & 2 & 3 & & & & & \\
\hline
\end{tabular}

browsing than more abundant species. Actually, species with lower abundance in 1981 (e.g., Polygonatum odoratum, Ixeridium dentatum, and Hakonechloa macra) were not recovered even after fencing. By grazing, tall-growing herbs were reduced and lower-growing species were increased [32] and grazing-resisted species were shorter in height than grazingsusceptible species [33]. Thus, tall herb species were tending to grazing and hard to recover after grazing. 


\section{Conclusions}

Preventing grazing after intensive grazing of seminatural grassland might result in different successional pathways being followed and the species composition is slightly different from the original vegetation. This suggests that the vegetation inside the fence will change to an alternative state [24]. Galvánek and Lepš [3] showed that the species composition of the restored plots after the reintroduction of mowing was still far from the target composition. Therefore, different management methods are needed to ensure the correct succession pathways are followed for ecological restoration and to enhance colonization of the target species [34], rather than the restored site resulting in an alternative state [24]. Thus, other methods to restore the vegetation (e.g., removing of unpalatable recalcitrant species [35]) inside of the fence would be necessary. Moreover, as Wright et al. [36] suggested, complete removal of ungulates may be required for recovery in heavily browsed forest understory vegetation in New Zealand. Hence, the control of sika deer population should be required.

\section{Conflict of Interests}

The authors declare that there is no conflict of interests regarding the publication of this paper.

\section{Acknowledgments}

The authors thank members of the Committee of Conservation of I. sanguinea on Mt. Kushigata and Dr. Masako Kubo (Shimane University) and Dr. Hayato Iijima (Yamanashi Forest Research Institute) for helping with the field study and Ms. Atsuko Hayashi (Forest and Forest Products Research Institute) for finding the references.

\section{References}

[1] T. Suka, "A history of semi-natural grasslands and its causation to distribution of grassland species," Grassland Science, vol. 56, pp. 225-230, 2010 (Japanese).

[2] M. Kubo, T. Kobayashi, M. Kitahara, and A. Hayashi, "Seasonal fluctuations in butterflies and nectar resources in a seminatural grassland near Mt. Fuji, central Japan," Biodiversity and Conservation, vol. 18, no. 1, pp. 229-246, 2009.

[3] D. Galvánek and J. Lepš, "How do management and restoration needs of mountain grasslands depend on moisture regime? Experimental study from north-western Slovakia (Western Carpathians)," Applied Vegetation Science, vol. 12, no. 3, pp. 273282, 2009.

[4] T. Nagaike, T. Yoshida, H. Miguchi, T. Nakashizuka, and T. Kamitani, "Rehabilitation for species enrichment in abandoned coppice forests in Japan," in Restoration of Boreal and Temperate Forests, J. A. Stanturf and P. Madsen, Eds., pp. 371-381, CRC Press, Boca Raton, Fla, USA, 2005.

[5] T. Kira, "Forest ecosystems of east and southeast Asia in a global perspective," Ecological Research, vol. 6, no. 2, pp. 185-200, 1991.

[6] Koma High School, "Iris sanguinea on Mt. Kushigata," 1986.

[7] N. Agetsuma, "Ecological function losses caused by monotonous land use induce crop raiding by wildlife on the island of Yakushima, southern Japan," Ecological Research, vol. 22, no. 3, pp. 390-402, 2007.

[8] H. Iijima, T. Nagaike, and T. Honda, "Estimation of deer population dynamics using a bayesian state-space model with multiple abundance indices," Journal of Wildlife Management, vol. 77, pp. 1038-1047, 2013.

[9] S. Takatsuki, "Effects of sika deer on vegetation in Japan: a review, Biological Conservation, vol. 142, no. 9, pp. 1922-1929, 2009.

[10] T. Takeuchi, T. Kobayashi, and M. Nashimoto, "Altitudinal differences in bark stripping by sika deer in the subalpine coniferous forest of Mt. Fuji," Forest Ecology and Management, vol. 261, no. 11, pp. 2089-2095, 2011.

[11] R. Tsujino and T. Yumoto, "Effects of sika deer on tree seedlings in a warm temperate forest on Yakushima Island, Japan," Ecological Research, vol. 19, no. 3, pp. 291-300, 2004.

[12] Z. Jiang, H. Ueda, M. Kitahara, and H. Imaki, "Bark stripping by sika deer on veitch fir related to stand age, bark nutrition, and season in northern Mount Fuji district, central Japan," Journal of Forest Research, vol. 10, no. 5, pp. 359-365, 2005.

[13] T. Nagaike and A. Hayashi, "Bark-stripping by Sika deer (Cervus nippon) in Larix kaempferi plantations in central Japan," Forest Ecology and Management, vol. 175, no. 1-3, pp. 563-572, 2003.

[14] T. Kamei, K.-I. Takeda, K. Koh, S. Izumiyama, O. Watanabe, and K. Ohshima, "Seasonal pasture utilization by wild sika deer (Cervus nippon) in a sown grassland," Grassland Science, vol. 56, no. 2, pp. 65-70, 2010.

[15] T. Nagaike, "Effects of browsing by sika deer (Cervus nippon) on subalpine vegetation at Mt. Kita, central Japan," Ecological Research, vol. 27, no. 2, pp. 467-473, 2012.

[16] S. Takatsuki, "Edge effects created by clear-cutting on habitat use by sika deer on Mt. Goyo, northern Honshu, Japan," Ecological Research, vol. 4, no. 3, pp. 287-295, 1989.

[17] T. Nagaike, "Effects of altitudinal gradient on species composition of naturally regenerated trees in Larix kaempferi plantations in central Japan," Journal of Forest Research, vol. 15, no. 1, pp. 65-70, 2010.

[18] J. Beguin, D. Pothier, and S. D. Côtá, "Deer browsing and soil disturbance induce cascading effects on plant communities: a multilevel path analysis," Ecological Applications, vol. 21, no. 2, pp. 439-451, 2011.

[19] M. Suzuki, "Succession of abandoned coppice woodlands weakens tolerance of ground-layer vegetation to ungulate hervivory: a test involving a field experiment," Forest Ecology and Management, vol. 289, pp. 318-324, 2013.

[20] H. Itô and T. Hino, "How do deer affect tree seedlings on a dwarf bamboo-dominated forest floor?" Ecological Research, vol. 20, no. 2, pp. 121-128, 2005.

[21] P. M. Perrin, F. J. G. Mitchell, and D. L. Kelly, "Long-term deer exclusion in yew-wood and oakwood habitats in southwest Ireland: changes in ground flora and species diversity," Forest Ecology and Management, vol. 262, no. 12, pp. 2328-2337, 2011.

[22] N. L. Schultz, J. W. Morgan, and I. D. Lunt, "Effects of grazing exclusion on plant species richness and phytomass accumulation vary across a regional productivity gradient," Journal of Vegetation Science, vol. 22, no. 1, pp. 130-142, 2011.

[23] C. Deléglise, G. Loucougaray, and D. Alard, "Spatial patterns of species and plant traits in response to 20 years of grazing exclusion in subalpine grassland communities," Journal of Vegetation Science, vol. 22, no. 3, pp. 402-413, 2011. 
[24] K. N. Suding, K. L. Gross, and G. R. Houseman, "Alternative states and positive feedbacks in restoration ecology," Trends in Ecology and Evolution, vol. 19, no. 1, pp. 46-53, 2004.

[25] V. Aschero and D. García, "The fencing paradigm in woodland conservation: consequences for recruitment of a semi-arid tree," Applied Vegetation Science, vol. 15, pp. 307-317, 2012.

[26] A. Shoji, H. Hayashi, K. Kohyama, and H. Sasaki, "Effects of horse grazing on plant species richness and abundance of Iris setosa in a boreal semi-natural grassland, Japan," Grassland Science, vol. 57, no. 1, pp. 1-8, 2011.

[27] B. McCune and M. J. Mefford, "PC-ORD. Multivariate analysis of ecological data," ver. 4, MjM Software Design, Gleneden Beach, Ore, USA, 1999.

[28] J. Lepš and V. Hadincová, "How reliable are our vegetation analyses?” Journal of Vegetation Science, vol. 3, pp. 119-124, 1992.

[29] A. Tamura, "Effect of time lag of establishment of deer-proof fences on the recovery of perennial herbs in a cool temperate deciduous forest diminished by sika deer browsing in the Tanzawa Mountains, central Japan," Japanese Journal of Conservation Ecology, vol. 15, no. 2, pp. 255-264, 2010 (Japanese).

[30] H. Olff and M. E. Ritchie, "Effects of herbivores on grassland plant diversity," Trends in Ecology and Evolution, vol. 13, no. 7, pp. 261-265, 1998.

[31] T. P. Rooney and W. J. Dress, "Species loss over sixty-six years in the ground-layer vegetation of heart's content, and old-growth forest in Pennsylvania, USA," Natural Areas Journal, vol. 17, no. 4, pp. 297-305, 1997.

[32] K. J. Kirby, "The impact of deer on the ground flora of British broadleaved woodland," Forestry, vol. 74, no. 3, pp. 219-229, 2001.

[33] S. Lengyel, K. Varga, B. Kosztyi et al., "Grassland restoration to conserve landscape-level biodiversity: a synthesis of early results from a large-scale project," Applied Vegetation Science, vol. 15, no. 2, pp. 264-276, 2012.

[34] S. Díaz, I. Noy-Meir, and M. Cabido, "Can grazing response of herbaceous plants be predicted from simple vegetative traits?" Journal of Applied Ecology, vol. 38, no. 3, pp. 497-508, 2001.

[35] T. Nuttle, T. E. Ristau, and A. A. Royo, "Long-term biological legacies of herbivore density in a landscape-scale experiment: forest understoreys reflect past deer density treatments for at least 20 years," Journal of Ecology, vol. 102, no. 1, pp. 221-228, 2014.

[36] D. M. Wright, A. J. Tanentzap, O. Flores et al., "Impacts of culling and exclusion of browsers on vegetation recovery across New Zealand forests," Biological Conservation, vol. 153, pp. 6471, 2012. 

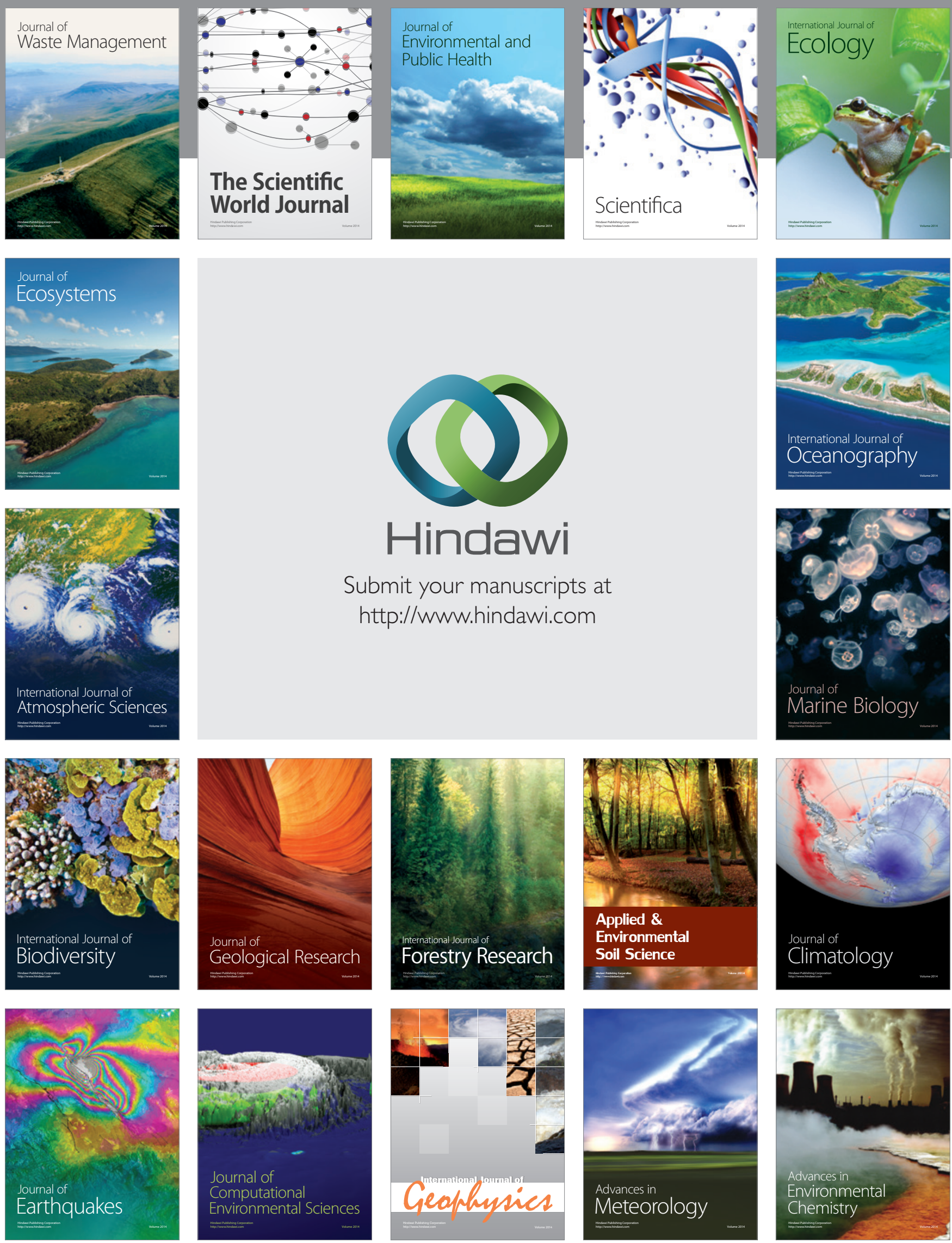